\title{
Eurostudia
}

\section{Church Collaboration and Resistance under Communism Revisited: The Case of Patriarch Justinian Marina (1948-1977)}

\section{Lucian Turcescu et Lavinia Stan}

Volume 10, numéro 1, 2015

From Today's Observation Post: Collaboration and Resistance under Communism

Vues du poste d'observation du présent : collaboration et résistance sous le communisme

Kollaboration und Widerstand im Kommunismus - Betrachtungen aus heutiger Sicht

URI : https://id.erudit.org/iderudit/1033883ar

DOI : https://doi.org/10.7202/1033883ar

Aller au sommaire du numéro

Éditeur(s)

Le Centre canadien d'études allemandes et européennes

ISSN

1718-8946 (numérique)

Découvrir la revue

Citer cet article

Turcescu, L. \& Stan, L. (2015). Church Collaboration and Resistance under Communism Revisited: The Case of Patriarch Justinian Marina (1948-1977). Eurostudia, 10(1), 75-103. https://doi.org/10.7202/1033883ar
Résumé de l'article

This article revisits the history of the Romanian Orthodox Church under communism and its instrumentalization after 1989 by focusing on the figure of Patriarch Justinian Marina (1948-1977). It argues that one of his successors and protégées, Patriarch Teoctist Ar\&abreve;pașu (1986-2007), had an interest in repainting Marina's relation to the communist regime as opposition, more than collaboration, because he viewed the opening of the Securitate archives in 2000 with alarm, given the large number of Securitate informers among the Orthodox clergy. It then presents a debate that has taken place in post-1989 Romania about Patriarch Justinian, and concludes that a deeper understanding of the history of ROC under early communism is possible only if Justinian is seen as both a collaborator with the regime and a defender of the ROC.
Tous droits réservés $@$ Le Centre canadien d'études allemandes et européennes, 2015
Ce document est protégé par la loi sur le droit d'auteur. L'utilisation des services d’Érudit (y compris la reproduction) est assujettie à sa politique d'utilisation que vous pouvez consulter en ligne.

https://apropos.erudit.org/fr/usagers/politique-dutilisation/ 


\title{
Lucian Turcescu \\ Concordia University \\ Lavinia Stan \\ St. Francis Xavier University
}

\begin{abstract}
:
This article revisits the history of the Romanian Orthodox Church under communism and its instrumentalization after 1989 by focusing on the figure of Patriarch Justinian Marina (1948-1977). It argues that one of his successors and protégées, Patriarch Teoctist Arăpașu (1986-2007), had an interest in repainting Marina's relation to the communist regime as opposition, more than collaboration, because he viewed the opening of the Securitate archives in 2000 with alarm, given the large number of Securitate informers among the Orthodox clergy. It then presents a debate that has taken place in post-1989 Romania about Patriarch Justinian, and concludes that a deeper understanding of the history of ROC under early communism is possible only if Justinian is seen as both a collaborator with the regime and a defender of the ROC.
\end{abstract}

\section{Introduction}

The topic of church-state relations under communism has been hotly debated during the recent decades in Central and Eastern Europe in general, and Romania in particular. This increased attention has resulted from an unparalleled wealth of data available on the topic. Previously unavailable secret, party and church archives have been opened to researchers; former church leaders and faithful have written numerous memoires and testimonials on the persecution they endured at the hands of the communist authorities; and former secret officers who placed religious denominations under surveillance have also come forward to present their points of view. This data combined has offered us a 
more nuanced, if yet incomplete, picture of church-state relations under communism.

This article reviews the debate on whether the Romanian Orthodox Church (ROC), the dominant religious group in Romania, collaborated with or resisted against communist authorities by focusing on Justinian Marina, the ROC Patriarch (1948-1977) during most of the communist period, beginning with its early years. It argues that to date scholars working on this topic have generally been divided into two major camps, each including historians, political scientists, theologians, religious studies scholars, and journalists, some working in Romania, others outside of the country. We will name some of them later in the article, arguing that one group has maintained that by and large the ROC collaborated with the communist authorities, gave in to communist demands even when those undermined church interests, and subordinated its goals to those of the regime. For this group of observers, the church and its members were mere instruments of the repressive regime, some willing and others unwilling. By contrast, the other group insists that the church has mainly resisted the communist regime, rejected many of its key demands, and pursued its agenda often in opposition to the party-state and its secret political police. For these scholars, the church and its members were victims of communism, worth celebrating.

We further argue that much of the debate on the church's collaboration with/resistance against the communist regime has revolved around the figure of Patriarch Marina, the longest reigning patriarch of the ROC. Justinian led the church at a time when the communists consolidated their rule through the use of extensive repression. The first decades of communist rule were marked by numerous arrests and imprisonments, deportations, and extra-judicial killings perpetrated by a regime that was Stalinist in nature. Many bishops, priests, monks, nuns, and ordinary believers were tortured and died in the communist prison system, the so-called Romanian Gulag. The scholarship to date has yielded significant insights into the complex and rather enigmatic life of Justinian and his relationship with the communist regime, especially under the leadership of Petru Groza (1945-1953) and Gheorghe Gheorghiu-Dej (1953-1965). We argue, however, that neither group mentioned above has accurately painted Justinian's 
complex relationship with the communist authorities, and propose a new interpretation drawing on both groups' findings. Doing this will advance the scholarship on the ROC's collaboration/resistance under communism.

We begin by briefly looking into the history of the ROC under communism, and then examine its reconsideration and instrumentalization after 1989. Besides the groups mentioned above, two religious actors have contributed to the debate on the relationship of the ROC with the communist regime: the minority Greek Catholic Church and Teoctist Arăpașu, the Orthodox Patriarch from 1986 to 2007. Disbanded in 1948 and forced to go "underground," the Greek Catholic Church was an obvious victim of the communist regime. Therefore, it had a legitimate interest in the reconsideration of the communist-era history of the ROC, because it wanted both to showcase its opposition to the communist regime at a time when the ROC benefited from its collaboration and to validate its claims to receive back the property it lost to the ROC in 1948. In his turn, Teoctist had an interest in repainting the ROC's ties to the communist regime as opposition, more than collaboration, because he viewed the opening of the Securitate archives in 2000 with alarm, given the large number of Securitate informers among the Orthodox clergy. This historical survey helps us to position the main characters and actors of the debate, Patriarchs Justinian and Teoctist. We then present the debate in so far as it relates to Patriarch Justinian, and conclude that a deeper understanding of the history of ROC under early communism is possible only if Justinian is seen as both a collaborator with the regime and a defender of the ROC.

\section{The Romanian Orthodox Church under Communism}

According to the 2011 national census, Romania's dominant religious group is the Orthodox Church, which claims the allegiance of some 86 percent of the country's total population of 19 million. Other large groups are the Roman Catholic Church (4.6 percent), the Reform Church (3.2 percent), and the Pentecostal Church (1.9 percent). The Greek Catholic Church United with Rome represents less than 1 percent, Judaism under 0.1 percent, and atheists also under 0.1 percent. Some 0.3 percent of the population belongs to Islam. The Roman Catholic and Reform churches attract many ethnic Hungarians living in Transylvania. The country's Romanian majority represents 91 percent of the total 
population, the Hungarians and the Roma amount to 6.6 and 1.3 percent, respectively, while other ethnic groups are below 1.3 percent. $^{1}$

After the creation of the modern Romanian state following the incorporation of the multi-religious and multi-ethnic region of Transylvania into the Romanian Kingdom in 1918, the 1923 Constitution failed to permit all religious groups to worship freely, or to insist that the state treat them equally. According to Article 22, "the Orthodox and the Greek Catholic Churches are Romanian Churches. The Romanian Orthodox Church, being the religion of a majority of Romanians, is the dominant Church in the Romanian state; the Greek Catholic Church has priority over other denominations." ${ }^{2}$ While this privileged position fell short of full autonomy from the secular power, it granted the dominant church key privileges, including government subsidies for clergy salaries and pensions. Article 133 of the same Constitution also ratified a 1919 law extending Romanian citizenship to the country's Jewish population, while allowing other Jews to apply for it for a limited time. While representing a major step in the emancipation of Romania's Jews, this policy led to a backlash from ultranationalist and fascist groups such as the Iron Guard (Grigore 2015; Clark 2015). Before the Iron Guard existed in the larger context of the rise of European fascism, the Romanian politician A. C. Cuza founded his National Christian Defense League (Liga Apărării Național-Creștine, or LANC) in 1922, with the young Corneliu Zelea-Codreanu (1899-1938) as a prominent member. ZeleaCodreanu eventually disagreed with Cuza's views and in 1927 founded his own Iron Guard Movement (Garda de Fier or Mișcarea Legionară-the Legionary Movement); its members were referred to as "Iron Guardists" or "legionaries." Both parties, which were virulently anti-Semitic, appealed to many Orthodox clergy and laity. These pre-communist allegiances came to haunt clergy members during communist times.

Following the end of World War II in 1945, Romania became part of the Soviet communist block. The Communist Party initially saw religion as a capitalist remnant expected to wither away as its social basis was expected to

\footnotetext{
${ }^{1}$ For the 2011 census, see Romanian National Institute for Statistics, Populatia stabila dupa religii, 2011, available at: http: / / www.recensamantromania.ro/ rezultate-2 (accessed 13 January 2015).

${ }^{2}$ The Romanian Constitution of 1923 available at http://www.constitutia.ro/const1923.htm (accessed 15 August 2010).
} 
disappear, but the party's religious policy was ultimately determined by practical more than ideological considerations. The communist religious strategy was multipronged, seeking to divide and conquer. Several waves of repression were launched to weed out church members who supported "retrograde" anticommunist positions. The state nationalized church property, severely restricted the training of priests, closed down confessional schools, and banned the teaching of religion in public schools and public religious celebrations of Easter and Christmas (Stan and Turcescu 2007: 65-66; Bărbulescu et al. 2012: 41112). Following the Soviet model, a dedicated secret political police (the Securitate) was to enact the repression needed to achieve the party's goals. The Securitate had to penetrate the rank and file of religious groups, marginalize, compromise, and ultimately destroy the lives of politically unreliable clergymen.

Churches whose leadership resided abroad were the first to be targeted for persecution. After the Concordat with the Roman Catholic Church was revoked in 1948, the communist state never sought to reach a compromise with that church, which continued its activity in the country under serious restrictions. Instead, the regime encouraged the establishment of a local Catholic Church independent from the Vatican. In 1948 the Greek Catholic Church was disbanded, its churches and adjacent land were transferred to the Orthodox Church, the state confiscated its other assets, and its leaders were imprisoned if refusing to convert to Orthodoxy. Ultimately the Greek Catholic disbanding proved to be a failure, as none of its bishops forcibly converted to Orthodoxy, preferring arrest instead. Many priests continued to serve illegally what was left of their flocks at the risk of their own lives. Over a dozen denominations historically present in the country were granted official recognition, but no other group was registered until 1989. The state let the faithful know that religion was not akin to the communist spirit by annulling the autonomy of denominations. In a symbolic gesture, in 1950 the authorities ordered the Baptists, the Seventh-day Adventists, and the Pentecostals to unite into the Federation of Protestant Cults. Threatened with obliteration, those groups could do nothing but obey (Turcescu and Stan 2010).

Despite severe restrictions imposed on the ROC's activities, many of its leaders (bishops, metropolitans, and four of five consecutive patriarchs) 
collaborated with the regime; if they refused, they would be replaced with men who obeyed. The clergy, monks, and nuns did not all collaborate, and many ended up in prison where some lost their lives. ${ }^{3}$ Patriarch Nicodim Munteanu (1939-1948) was the first to show signs of Orthodox support for the communists. Despite a 24 August 1944 letter he sent to King Michael to express support for his decision to abandon the country's alliance with Hitler, arrest Marshal Ion Antonescu, and join the Allied Forces on 23 August 1944, the patriarch issued a Pastoral Letter on 9 October 1944 in which "religious symbols [were mixed] with political messages aimed at changing the faithful's perception of the Soviet Union" (Leustean 2009: 57-59). This was a gesture of support for the Soviet Union, whose military forces were present in Romania, and of endorsement of their communist representatives in Romania. At the same time, under Prime Minister Groza the communists tried to use the ROC to gain popular support for their policies. Groza encouraged Patriarch Nicodim to visit Moscow and foster relations with the newly elected, Stalin-endorsed Patriarch Aleksi I (1945-1971) of the Russian Orthodox Church and a KGB agent of influence (Andrews and Mitrokhin 2001: 523). In 1947, Patriarch Aleksi I visited Romania to strengthen relations between the two sister Orthodox churches. The Securitate saw the visit as an opportunity for communist propaganda, but its reports noted that Patriarch Nicodim and many priests regarded the visit with suspicion (Leustean 2009: 67). Despite their leaders' support for communism, many Orthodox priests, monks, and nuns opposed the instauration of communism in the country and hoped the American troops would free Romania from Soviet occupation. Like lay believers who rejected communism, the clergy paid a heavy price for this hope, many of them being imprisoned and killed, alongside members of other religious denominations present in Romania.

A major supporter of communist policies was the Orthodox Church's next patriarch, Justinian Marina. Widowed parish priest Ioan (later Justinian) Marina was promoted to the church hierarchy due to his socialist views and the shelter he provided to high communist officials such as Gheorghe Gheorghiu-Dej and Ion Gheorghe Maurer, who had escaped from prison during Marshal Ion

\footnotetext{
${ }^{3}$ According to estimates, 17 Orthodox prelates were deprived of their seats, 15 prelates were exiled, while 1,888 Orthodox, 235 Greek Catholic, and 172 Roman Catholic priests, 67 Protestant pastors, 25 Neoprotestant, 23 Muslim imams, and 13 Jewish rabbis ware arrested under the communist regime in Romania (Caravia et al. 1999: 15).
} 
Antonescu's regime (1940-1944) (Leustean 2009: 179). Gheorghiu-Dej was in office from 1944 to 1965, although he obtained full control of the party only after the elimination of the Muscovite faction led by Ana Pauker in 1952. Justinian became Metropolitan of Moldova in 1947, and Patriarch upon the death of Nicodim in 1948. Another figure endorsing the ROC's collaboration with the communists was former Iron Guard priest Constantin Burducea, who was appointed Minister of Religious Denominations (1945-1946) after switching sides to support the communists. While short-lived, Burducea's opportunistic attempt to climb the communist ladder included speeches declaring that "The Church has an important role in uniting the people from the Soviet Union, Romanian and the Balkan states.... This collaboration between church and state is something normal, because the government belongs to the people, the Church is of the people, and all these three belong to God" (Leustean 2009: 62; Petcu 2012). In 1948, Burducea defected to neighboring Yugoslavia and then South America.

On 9 May 1946 Auxiliary Bishop of Iași, Justinian Marina, preached in favor of Romanian-Soviet collaboration, mixing religion and politics and comparing the day of Ascension into Heaven of Jesus with the day of ascension that has come for the Romanians with the presence of Soviet armies in the country. To eliminate any possible competition for Justinian in the upcoming race for the patriarchal seat, the Securitate forced bishops over the age of 70 to retire and replaced them with younger bishops obedient to the regime. The communists also falsified the country's elections of 19 November 1946 to stay in power. On 28 December 1947, on his enthronement as Metropolitan of Moldova, Justinian renewed his allegiance to the Groza government and urged the faithful to dedicate themselves to the "unprecedented work for the establishment of the social man, the man of peace, love, honor and work." ${ }^{4}$ These declarations took place as the communists were planning the ousting of King Michael, whom they saw as the final obstacle in their attempt to take over the country. The king abdicated on 30 December 1947, and then left Romania on 4 January 1948. On 30 December 1947 the National Assembly (controlled by the communists) hurried to declare Romania a People's Republic and to abolish the monarchy.

\footnotetext{
${ }^{4}$ Justinian Marina, Apostolat social (cited in Leustean 2009: 68).
} 
Soon after the death of Patriarch Nicodim, Justinian was appointed Patriarch with Moscow's approval on 24 May 1948. The regime rewarded him with numerous medals and privileges in the years to come. Justinian, as other Orthodox bishops under communism, enjoyed a lifestyle that was well above that of ordinary Romanians whose poverty deepened every day. To secure the authorities' support for his appointment, days before his election as Patriarch, Justinian published a volume of speeches outlining his vision about the collaboration between church and state. According to this doctrine, known as "social apostolate," "the church was subservient to the state as the 'servant church of the people,' while the state assured religious liberty" (Leustean 2009: 74). The doctrine build on the Byzantine symphonia between a Christian emperor and a Christian church and society. In his speech on the occasion of his appointment, the patriarch spoke about "the other sheep of mine, not belonging to this fold, whom I must bring in" (Leustean 2009: 74, Leustean 2014), an allusion to the dismantling of the Greek Catholic Church, scheduled for 21 October 1948. Justinian's church benefited from the disbanding of the Greek Catholic Church in Romania, whose places of worship were given to the ROC, and whose believers and clergy were offered the option to join the ROC or be outlawed.

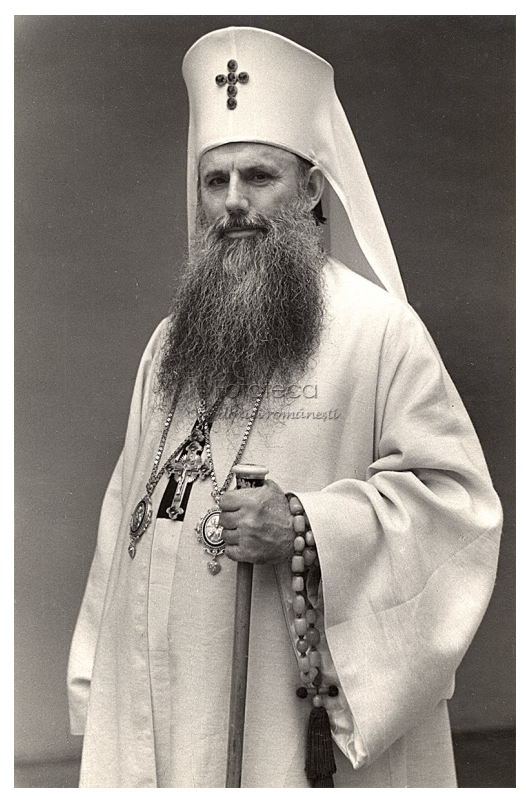

Photo 1 : Justinian Marina. CFototeca Ortodoxiei românești. 
On 4 August 1948, the communist government issued Decree no. 177, a new law on religious denominations. ${ }^{5}$ While emphasizing freedom of religion in the formally atheistic country, the law, which was enforced both during the entire communist period and partly after 1989, imposed many restrictions on the functioning of religions and brought religion under even tighter control by the government. According to the law, individuals seeking church leadership positions through elections had to be vetted by the Great National Assembly which was the Communist Party-controlled parliament and take an oath of allegiance to the regime, swearing to defend the country against its internal and external enemies, ensuring that they and their subordinates would respect the laws of the People's Republic and would not engage in activities that contravened to the new political order. Bishop Nicolae Popovici of Oradea, who preached against the communists, was excluded from the church hierarchy as a result of the new law (Leustean 2009: 78-79). Thus, after 1948 dissent and conflict within the ranks of Orthodoxy hierarchy was very limited. When it existed, it was manifested though disagreements between the patriarch and opportunistic bishops who wanted to climb the hierarchical ladder faster (e.g. Iusin Moisescu, who will be mentioned later in this article). The opening of the ROC archives will likely shed more light on whether or not Synod members manifested disagreements with Justinian.

The communists persecuted but did not dismantle the ROC, recognizing instead that a church respected by the population could further the party's socioeconomic and political goals. In doing so, the communists showed that they did not respect religious authority. Until 1965 the state sought to weaken the church's social role and bring its hierarchy under control by depriving the church of its national church status and the right to pursue educational and charitable activities. Once the last remnants of resistance were crushed, the state enlisted the ROC as an unconditional supporter of communist policies in return for the government tolerating some ecclesiastical activity.

\footnotetext{
${ }^{5}$ Ministry of Religious Denominations, "Decret Nr. 177 din 4 august 1948 pentru regimul general al cultelor religioase" Monitorul Oficial no. 178 (4 August 1948) at http://www.monitoruljuridic.ro/act/ decret-nr-177-din-4-august-1948-pentru-regimul-general-al-cultelor-religioase-emitent-ministerulcultelor-publicat-n-47.html (accessed 20 August 2015).
} 


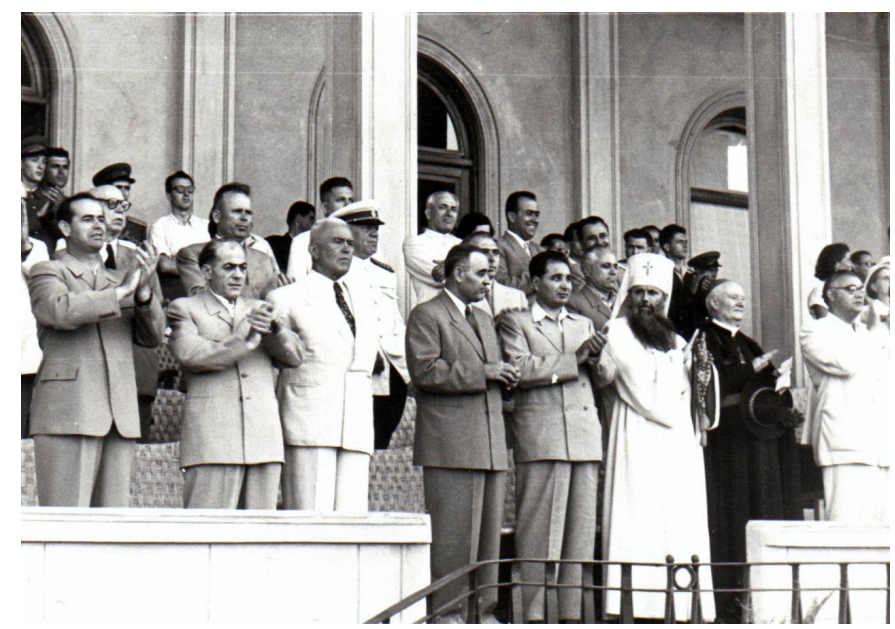

Photo 2: Patriarch Justinian and communist leadership (1953). (C)Fototeca online a comunismului românesc.

Patriarch Justinian's cooperation, however, did not spare the Church several waves of persecution, including depositions and arrests of clergy, closure of monasteries and monastic seminaries, and strict control of its relations with foreign churches (Beeson 1982: 368). Following the 1949 "social reorientation" programs, numerous priests considered retrograde were arrested. Another wave of arrests took place in the late 1950s, when additional monastic seminaries and monasteries were closed down, and thousands of monks and nuns were jailed or forced to go "back into the world" (Aioanei and Moraru 2001: 89-90; Dură 1994). According to the Decree 410 of 28 October 1959, only men aged 55 and over, and women aged 50 and over were to be admitted into monasticism, and the measure was to be applied retroactively to 1948. Thus, of the 6014 monks and nuns estimated to live in monasteries as of 1 January 1959, 4750 were to be removed following the application of the decree. Of the 192 monasteries the Securitate estimated to be in existence at the beginning of that year, 92 were to be closed as a result of the lack of monastic personnel following the removal of monks and nuns by the application of the decree (Enache 2009). In response, Justinian reformed the monastic system to prevent it from being viewed as an anachronism unrelated to the life of socialist Romania. He introduced "useful trades" that every monk and nun could practice, including the production of clerical and monastic garb, carpets, painting, embroidery, sculpting, but also carpentry. 
The 1965-1977 period saw a relative thaw in church-state relations. The state no longer closed down monasteries, agreed to rehabilitate formerly imprisoned clergy, and financially supported the restoration of churches of historical importance and the building of a limited number of churches (Sincan 2010). Communist dictator Nicolae Ceauşescu used the ROC to gain independence from Moscow in order to ingratiate himself with the West, whose financial support he needed badly for his megalomaniac industrialization projects. He also sought to strengthen his position domestically by appealing to nationalism, which the Church considered its turf. In 1968 Ceauşescu acknowledged the role of the ROC in the development of modern Romania, and also tacitly tolerated the use of the baptism, marriage, and burial services by communist officials who privately considered themselves Orthodox Christians. In May 1974, Justinian in turn brought the ROC into the Socialist Unity and Democracy Front, a national advisory organization totally controlled by the Communist Party. Justinian's death in 1977 coincided with the revival of an East European civil society and the onset of a new anti-church campaign in Romania.

Shortly after his appointment in 1977, Patriarch Iustin Moisescu rendered homage to Ceauşescu for "securing complete freedom for all religious cults in our country to carry out their activity among the faithful" and for his forty-fiveyear-long activity "devoted to the progress of the Romanian people and fatherland" (Webster 1995: 111). A former legionary turned Communist Party member and Securitate informer, Iustin had an impressive ascent in the Orthodox hierarchy as early as the 1950s, but only managed to become patriarch after Marina's death in 1977. His Securitate file is still classified in the archives of the Romanian Information Service and thus unavailable for researchers to consult (Duca 2007).

By 1979 religious persecution was on the rise again, and the regime continued its antireligious policies unabated until 1989. Under Iustin, the ROC leadership continued to support the regime by allowing for the demolition of historically and architecturally important monuments such as the Schitul Maicilor and Cotroceni monasteries, as well as numerous other churches in order to accommodate Ceauşescu's architectural ambitions. It also continued to tell in the West that there was full freedom of religion in Romania. Several voices from 
among the clergy, however, stood up against Ceauşescu's blatant infringements of religious freedom. The best known dissenter was an Orthodox priest named Gheorghe Calciu-Dumitreasa who was sentenced in 1979 to prison and later banished into exile for preaching sermons labeling atheism as a philosophy of despair, and criticizing the regime's violations of human rights and church demolitions. Iustin allowed the Synod to defrock Calciu-Dumitreasa and other priests who were later arrested for anticommunist opposition. Between 1977 and 1989, twenty-two churches and monasteries were demolished and fourteen others were closed down or moved to disadvantageous sites behind tall apartment blocks to make room for Ceauşescu's megalomaniac redesign plans for Bucharest.

Iustin's successor, Teoctist Arăpaşu (who ruled from 1986 to 2007), a political activist long before becoming patriarch, served as a Grand National Assembly deputy, a delegate to the Socialist Unity and Democracy Front congresses, and a key member of the Ceauşescu-sponsored National Peace Committee. Patriarch Teoctist struggled with Ceauşescu's desire to demolish the Bucharest patriarchal complex and transfer the See to the northeastern town of Iaşi (Stan and Turcescu 2006: 1119-1139). As a result of his opposition, Elena Ceauşescu decided to demolish the Văcărești monastic complex and monastery in 1987. This did not prevent him from sending the dictator a telegram of support days after the first popular anticommunist uprising started in Timişoara in December 1989.

On 19 December 1989, on behalf of the ROC Synod and the National Church Assembly meeting held two days earlier, Teoctist sent a congratulatory telegram to Ceauşescu on his re-election as Communist Party secretary general. At that time, the anti-Ceauşescu revolt in Timissoara was in full swing and foreign radio stations already talked about many dead protesters after Ceauşescu ordered the suppression of the revolt. It was impossible for Teoctist to claim he did not know about the revolt. Yet, his telegram did not take a stand against the murdering of protesters. Instead, couched in the communist "wooden language," it applauded the accomplishments of the Ceauşescu couple and made references to the imminent new year, thus making it evident that it was issued on December 19 and not weeks before, as some commentators argued in an effort to salvage 
the church's image. ${ }^{6}$ Teoctist tried to explain away why the Synod sent the telegram, by arguing unconvincingly that the telegram was a requirement of the Secretariat of State for Religious Denominations that went out automatically on festive occasions. Unfortunately, the telegram itself, and the fact that the doors of the Orthodox cathedral in Timis,oara were kept locked during the protests of 1621 December 1989 suggests concerted support for Ceauşescu by the ROC during the revolution.

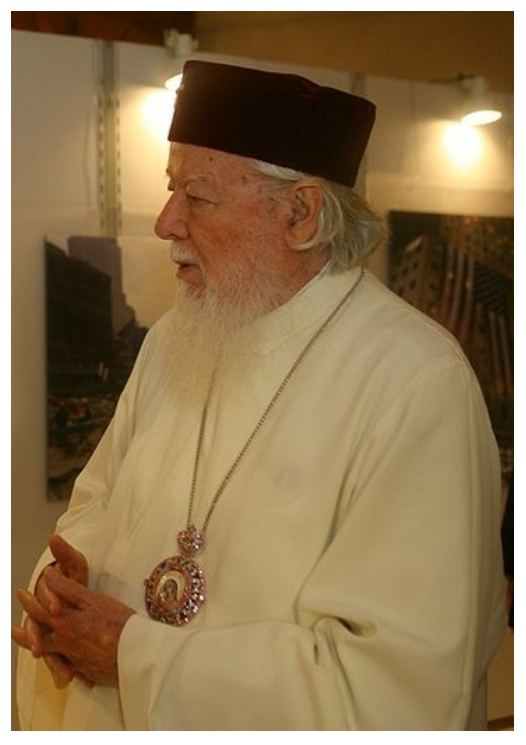

Photo 3: Patriarch Teoctist. (C)ikimedia.

Following the Romanian revolution and the execution by firing squad of the Ceauşescu couple on Christmas day 1989, Teoctist expressed regrets that his church did not have the courage of the martyrs to oppose communism. Weeks later, on 18 June 1990, following widespread criticism of the telegram and citing diplomatically "reasons of health and age," Teoctist resigned his position as patriarch. He withdrew to the Sinaia monastery, but was later recalled by the Synod members-many of whom were fellow supporters of the communist regime and just as compromised as Teoctist-to resume his role as leader of the church. Teoctist never raised the issue of his collaboration with the communists until 2000, in a 5 January 2000 interview with the BBC, in which he decided to

${ }^{6}$ „Telegramă," România liberă (20 December 1989: 3). 
cast himself and his church as victims of the communist regime (Stan and Turcescu 2007: 71).

\section{The Post-Communist Instrumentalization of Church History}

Patriarch Teoctist's withdrawal and timid contrition led many intellectuals to point out the ROC's collaboration with the communist regime until 1989. These voices, mainly grouped around the respected 22 weekly of the Bucharest-based Group for Social Dialogue, were joined by Greek Catholic leaders of the National Christian Democrat Peasant Party, who criticized the ROC as an institution and its leaders individually for not even once publicly opposing communist antireligious policies. The debate on the ROC's relationship with the communist regime grew during the 1990s, when two major camps presented opposite views. On one hand, the ROC, through its leaders, scores of priests and some faithful, underscored the suffering the church endured until 1989, pointing out the numerous cases of priests and faithful who spent considerable time in prison or were harassed by the Securitate for their faith. On the other hand, some intellectuals, secular or Orthodox, and the Greek Catholics emphasized the many instances when the ROC supported or at least did not oppose communist policies. Surely, the history of the ROC from 1945 to 1989 included as many instances of ROC active and tacit collaboration as of ROC resistance and opposition.

Note that until 2000, when the first secret files compiled by the communist Securitate became available to researchers and the general public, this entire debate relied on information drawn from other sources, primarily the testimonials of former political prisoners and personal recollections of the participants in this debate about life under communism. The ROC continues to keep its archives under lock, selectively releasing information only if it furthers the position of its leaders, who have argued in favor of its communist-era resistance. Only very few collections of the Communist Party archives were made available, a limited number of which directly spoke about the way in which the communist regime viewed religion, denominations, or religious leaders. 
In 1999, however, Law 187 allowed journalists, researchers, and members of the public to gain access the extant Securitate archives not touching on "national security." Access is granted by the National Council for the Study of Securitate (CNSAS), an independent governmental agency recognized as the archive custodian. Since the secret archives were housed with the Romanian Information Service (SRI), the heir to the Securitate, nobody but the former secret agents knew the extent of the collected information, and many files were kept under lock for touching on "national security" with access being very restricted and partial. But the archival collections turned to be a treasure trove for scholars of religion and politics participating in the debate. Several edited volumes of Securitate documents suggested that key ROC leaders praised the communist regime and endorsed its policies. At the same time, there was evidence of great suffering of priests, many of them thrown into prison for their pre-communist collaboration with and sympathy for the Iron Guard, which the ROC supporters interpreted as evidence of victimization for Christ and anticommunist sentiment.

An ever growing number of opened Securitate files has allowed the CNSAS to document the secret collaboration with the Securitate of many Orthodox priests, bishops, metropolitans, and even patriarchs. Despite allegations that the documents to which the CNSAS has access are not genuine but have been altered after 1989, do not depict communist-era reality but reflected the distorted views of overbearing authorities, and should not be interpreted with post-communist standards of human rights protection in mind as they served a repressive regime, the CNSAS has handed out verdicts of collaboration to a number of Orthodox hierarchs such as Bishop Andrei Andreicut, of Cluj, Archbishop Pimen Zainea of Suceava, and Bishop Calinic Argatu of Arges, Some verdicts survived appeals in courts of law and remained definitive. Collectively, these verdicts suggest that a large number of Orthodox clergy accepted to serve as the repressive tools of the communist regime, even offering information obtained through confession to the secret political police (Stan and Turcescu 2010: 154-161).

Notwithstanding the significant problems of reliability and accuracy raised by any attempt of interpreting the information contained in the secret documents, the Securitate archive became the main source of evidence in the 
debate on the ROC's relationship with the communists. Many saw the secret archives as more reliable than personal testimonials, probably because most Orthodox priests and hierarchs claimed to have suffered at the hands of the communists, and only a handful of them openly admitted to having served as snitches for the Securitate, spying on other priests and the faithful. The opening of the Securitate files, thus, reduced the debate to information derived from the secret files. The debate was even further limited by the intervention of Patriarch Teoctist, for whom the ROC's relationship with the communists boiled down to Patriarch Justinian's position toward the regime.

Teoctist was one of many former Iron Guard members who switched allegiances and became communist activists. A Securitate note dated 6 January 1949 talks about him as a person "who pretends he is a member of the Romanian Workers' Party and a democratic [that is, socialist] activist, although he was a member of the Cuza movement and then a legionary." ${ }^{7}$ A more serious allegation against Teoctist is found in two other Securitate notes dated 30 August 1949 and 30 January 1950, which portray Teoctist as a former Iron Guard member and a participant in the January 1941 fascist rebellion against Marshal Ion Antonescu that resulted in the death of 416 people, of which 120 were Jewish. ${ }^{8}$ According to one of the notes, the twenty-six-year-old Teoctist ransacked a Bucharest synagogue, together with other priests and Iron Guard members (Andreescu 2001; Catalan 2003: 142-151; Stan and Turcescu 2007: 7173). When this information first came to light in 2001, Gabriel Catalan, the researcher who viewed the notes and publicized the findings at the urging of historian Dorin Dobrincu, was promptly dismissed from the CNSAS. ${ }^{9}$ The Patriarchate rejected the notes as pure fabrication. In the two volumes of transcribed Securitate documents they edited, Cristina Păiușan and Radu Ciuceanu, two historians from the Romanian Academy's National Institute for the Study of Totalitarianism, removed the passage incriminating Teoctist as an

\footnotetext{
${ }^{7}$ Archive of the CNSAS (ACNSAS), Collection D, file no. 7755, vol. 3: 121 (Păiusan and Ciuceanu 2003: 25).

${ }^{8}$ ACNSAS, Collection D, file no. 909: 510.

${ }^{9}$ According to a former CNSAS employee who spoke to the authors of this article on condition of anonymity, following the incident about Teoctist's file, Gabriel Catalan was dismissed "on orders that came from above" without any investigation, in a hurried manner, and in such a way as to frighten other CNSAS employees.
} 
anti-Semite and homosexual (Păiușan and Radu Ciuceanu 2003: 165) in order to support the Patriarchate's interpretation of the documents.
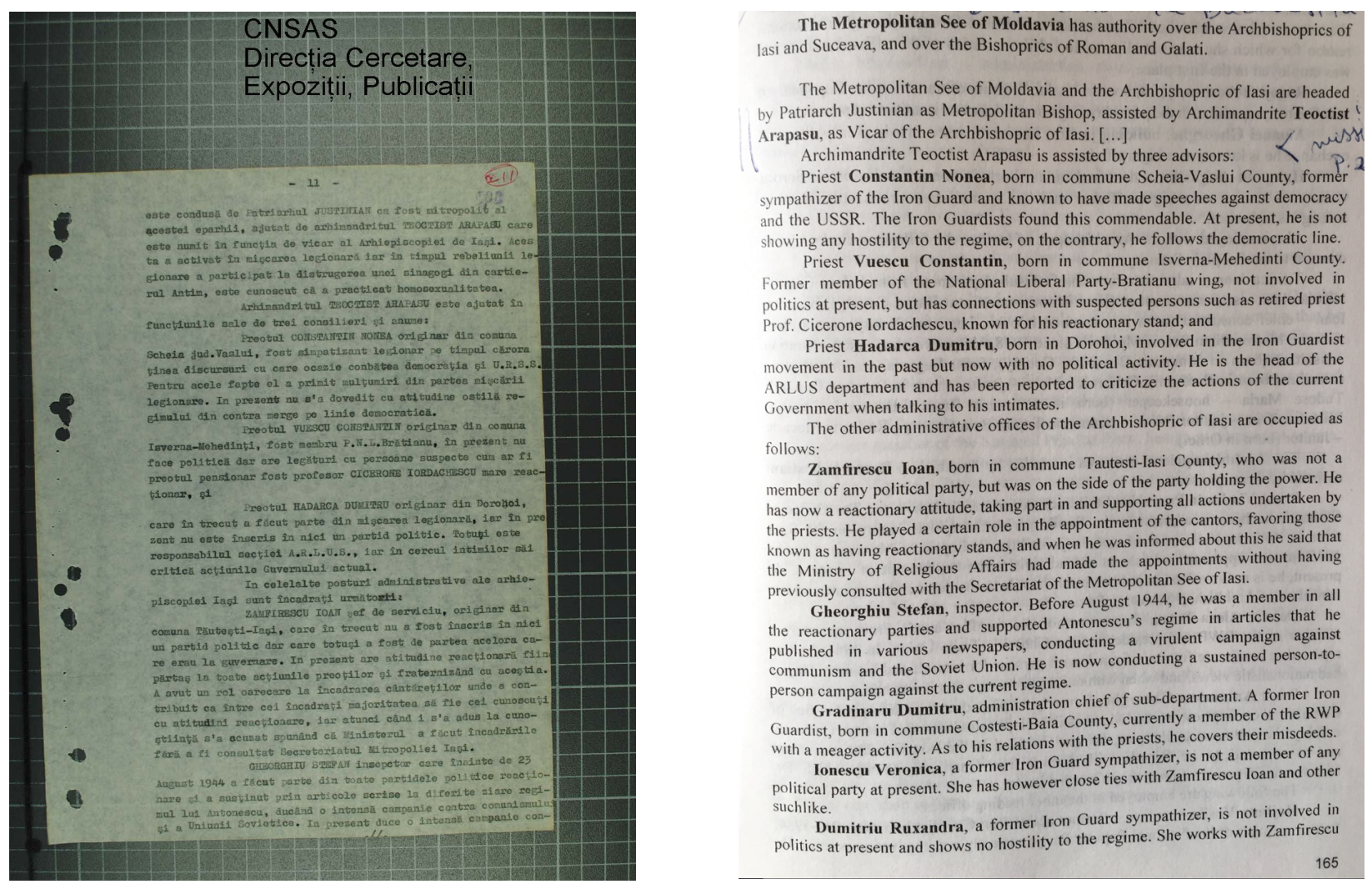

Photo 4: CNSAS file page. (CArchive of the CNSAS.

Photo 5: P.165 from Paiusan and Ciuceanu 2003.

Notwithstanding his Iron Guard past, young Teoctist was groomed and protected by Patriarch Justinian, who personally helped him to advance through the ROC leadership ranks at a time when many former Iron Guard members were punished with heavy prison sentences. Groomed and promoted by Justinian, Teoctist was present during the main events in the life of the ROC under communism as an authorized agent of Justinian. This personal history explains why Teoctist cast the Orthodox Church as a victim of communism by attempting to rehabilitate Justinian Marina. No similar attempts were made to rescue the reputation of Patriarch Iustin, a rival of Teoctist.

Another reason why Teoctist insisted on rehabilitating Justinian must be mentioned here. The focus on the first decades of communist rule allowed 
Patriarch Teoctist and the ROC to underscore the many cases of imprisoned and persecuted clergy. In Romania, the early communist rule of Gheorghiu-Dej was characterized by blatant human rights violations that indisputably qualified their targets as victims. To prove resistance of the church meant to amass information on the great number of priests and faithful persecuted for their religious and political views until 1964. Scores of former political prisoners testified to the presence of Orthodox priests in the Romanian communist prisons, the liturgies and baptism ceremonies they organized clandestinely, their bravery and sacrifice, and the guards' disdain and hatred against Orthodox students who were subjected to the terrifying Pitesti-type prison re-education experiments in order to transform them from real or imagined enemies into adherents of the communist ideology (Stănescu 2010-2012). After 1965, the Nicolae Ceauşescu regime closed down political prisons, and replaced outright repression with widespread surveillance by the Securitate. While the regime upheld the secret of the correspondence and other individual rights, the nature of communist infringements made it unclear whether priests could claim the status of victims when the society at large saw its basic rights and necessities drastically curtailed.

\section{Patriarch Justinian: Communist Collaborator or Church Defender?}

Let us now explain how the scholarship on church-state relations under communism depicts Patriarch Justinian. As mentioned earlier, some scholars view Justinian mainly as a collaborator, while others portray him as a hero of communist resistance and a defender of a church which otherwise would have been annihilated. These positions on the former patriarch align perfectly with opinions on the ROC's relationship with the communist authorities. Indeed, scholars who see Justinian as a collaborator also posit that the ROC mainly supported the regime, and only occasionally stood up to it; by contrast, scholars who see Justinian as the epitome of anticommunist resistance are also those who believe that the ROC diverged from the communist regime to the extent possible under a repressive dictatorship. While the voice arguing for Justinian's collaboration was louder in the 2000-2006 period, the other voice arguing for his

resistance has become increasingly louder over the last decade, including through the phenomenon of the "prison saints" (see Grigore 2015). We include below only a selection of quotes to illustrate the two divergent positions. 
The group who presents the ROC as a collaborator includes such scholars as Gabriel Catalan, Gabriel Andreescu, Cristian Vasile, Dorin Dobrincu, and Anca Șincan (who work within Romania), as well as Lucian Leuștean, Denis Deletant, Olivier Gillet, Cristian Romocea, Lavinia Stan and Lucian Turcescu (who work outside Romania). These scholars argue that Justinian had Moscow's endorsement in his appointment and most of what he did; he wrote convincingly and with zeal in support of communist policies; he was involved in the disbanding of the Greek Catholic Church in 1948; and he urged priests to support notorious communist policies (the collectivization of agriculture, and the creation of the new homo sovieticus). According to them, many Synod members collaborated in similar ways; many bishops and priests acted as Securitate secret informers; most clergy accepted salaries from the state; and overall, the Orthodox Church collaborated in exchange for the protection of its assets from nationalization and for a privileged position among denominations. Despite these arguments in favor of collaboration, these scholars recognize with respect the sacrifices of numerous other bishops, priests, monks, nuns, and ordinary faithful.

In a book published in 1997, before the opening of the Securitate archives, Belgian scholar Olivier Gillet wrote about Justinian's "social apostolate":

Social apostolate was not only an Orthodox adaptation of the communist politics, but also followed scrupulously the state directives. For the communist state, the church had to contribute to the edification of the new society, and for the church, the state had to insure a legal framework which guaranteed the liberty of religion. The church had an interest in collaborating with the state to secure its place in the national life and the state had everything to gain by obtaining the favors of the Orthodox church which constituted a dominant institution in the state and enjoyed a real prestige. The Orthodox church conveyed the politics and the propaganda of the state, and the state could count on the church to obtain a considerable support for its anti-western politics, especially the abolition of the Concordat [with the Roman Catholic Church] in 1948....Through the abrogation of the Concordat and the suppression of the Greek Catholic Church in 1948, the state restrained considerably the influence of Catholicism in Romania and the [Orthodox] Church recovered its prestige as dominant church. From now on, however, the Orthodox Church had to teach the citizens the respect for authority through a Christian patriotism that insured the state of the submission of the Orthodox Christians (Gillet 1997: 28-29; our translation). 
In noting the sometimes aggressive reactions following the 2001 publication of Gillet's book in Romanian translation, historian Cristian Vasile wrote that:

Unfortunately, some researchers from the CNSAS, in their desire to combat the arguments of Olivier Gillet, as well as the ecclesiastical history works published in exile, have fallen in the other extreme, transforming Patriarch Justinian Marina and other post-1948 hierarchs into some sort of heroes of the anti-communist resistance and ignoring all the sensible aspects from the recent past of Romanian Orthodoxy (the Greek Catholic question, the episode of the disbanding of the Vladimiresti monastery, etc.) (Vasile 2005: 19; our translation).

Vasile hints to Enache and Petcu as the CNSAS researchers who indefatigably and passionately sought to delegitimize Gillet's argument, by undermining his credibility as a historian, raising doubts that a foreign historian can really understand Romanian realities, and insisting that his volume ignores the large number of priests who lost their lives as a result of communist persecution.

On the other side of the debate are scholars in Romania who are very close to the Orthodox Church. They generally look at the suffering the priests, monks, nuns, and ordinary faithful endured during early communism and extend that suffering to most church leaders, beginning with Patriarch Justinian Marina, in order to cast the Orthodox Church as an institution in the role of a victim of communism. The group includes Cristina Păiușan, Radu Ciuceanu, Adrian Nicolae Petcu, and George Enache. They argue that Justinian resisted the communists and his church was a victim of communism; the ROC was placed under heavy surveillance by the Securitate; many clergy, monks, nuns, and faithful were arrested, imprisoned, tortured, or persecuted; Justinian did everything he could to defend the institution and its people, but he had to play by Soviet rules; the Securitate archives demonstrate amply that ROC was terrorized and victimized by the communists; Justinian "surrounded himself" by former Iron Guard members and thus undermined the communists and disregarded their policy of sidelining and persecuting their former right-wing rivals. 
In a collection of articles, Enache quotes numerous examples of churchstate collaboration that Patriarch Justinian proposed and justified in his writings (especially in his Social Apostolate volumes): approval of the new communist constitution, the collectivization of agriculture, the submission of citizens to the communist state and its ideology, dialectic materialism. In spite of these examples, Enache refuses to view them as collaboration and submission of the church to the state. Instead, he claims that the opening of the Securitate archives demonstrates that Justinian was a defender of the church:

At first sight the examples mentioned before are shocking and represent serious reasons for some historians to accuse the Romanian Orthodox Church of obedient collaborationism with the communist power. However, the recent opening of the archives of the former Securitate and making available to researchers some collections which were previously prohibited demonstrate the distance, sometimes enormous, that exists between what was presented in the official writings and the deaf confrontation that took place many times between the patriarch, on the one hand, and the state organs and the Securitate, on the other hand.... The "survival strategy" devised by Justinian becomes increasingly clear with every new document that is being published (Enache 2005: 67; our translation).

In examining the ROC's behavior during pre-communist times, Enache decides that, in welcoming the communist regime and supporting it, Justinian did not do anything different from his predecessors who welcomed all new regime changes in a similar way and assured the new authorities of the support of their church (Enache 2005: 83). He writes:

His [Justinian's] resistance was based on the logic of church-state relations that was already in place, on legalism, trying to speculate all the opportunities left with stinginess by the communist legislation and, not least, trying to use his personal relations with the power structure, as well as taking advantage of his skills as a good negotiator (Enache 2005: 90; our translation).

A parallel is then drawn between Justinian and the Romanian philosopher Constantin Noica, whose defenders claim that he practiced a "resistance through culture" rather than one of open opposition to the regime, despite the fact that he did that under the close surveillance of the Securitate. In doing so, Enache appeals to the concept of "spiritual resistance," which he and other defenders of 
the ROC use to explain the Church's attitude toward communism during trying times (Enache 2005: 91, n. 163).

In a biography of Patriarch Justinian, Enache and Petcu wrote:

Patriarch Justinian pursued a real and coherent strategy to protect from destruction the Romanian Orthodox Church. The basic principle of this strategy was the establishment of relations with the communist state based on mutual "loyalty," meant to constitute a guarantee for the assurance of a wider field of maneuver for the church in society. Patriarch Justinian hoped that, by being "fair" with the political power, the latter will respond in a similar way. To reach his goals, he made numerous concessions, but none for free.... He was not acting randomly, but always played a complex game from which the church was to gain something. In this game he also made mistakes, some serious, or he sacrificed persons; yet, that was done not on a whim, but in the hope that the church as a whole would be strengthened. This strategy seemed to yield results during his first ten years in power... But this very success was one of the major causes of the terrible blows the Church received in 1958-1961 (Enache and Petcu 2009: 223; our translation).

Cristina Păiușan also wrote that the communists regarded Justinian Marina as "one of the obedient hierarchs" who replaced older, "anti-democratic" church leaders. However,

Contrary to his being known as the Red Patriarch, Justinian proved to be a defender of the Church and not an informer. The secret police accused him throughout his tenure that he protected, even encouraged, the subversives: priests and monks, members of the former "historical parties," former legionaries, supporters of [Marshal Ion] Antonescu, and others. He was also blamed for having refused to allow the interference of priests who were party members in the running of the Church. The accusations of supporting the legionaries and of collaboration with the Legionary and the Antonescu regimes, most frequently used by the repression bodies to discredit clerics, did not have to be proved, suspicion being sufficient evidence. Such accusations... referred to most hierarchs who considered it their duty to defend the interests of the Church (Păiușan 2003: 19-20; our translation).

Elsewhere, Păiușan wrote that the ROC was "one of the institutions most monitored by the Securitate during the 45 years of the communist regime. Today, the Church is treated as a Securitate 'collaborator.' From the high prelates to the ordinary priest, priests and monks are labeled as simply collaborators of an institution that terrorized them for life" (Păiușan 2011; our translation). 


\section{Understanding Patriarch Justinian's Complex Relations with the Communists}

The historical overview presented above makes it clear that Patriarch Justinian ruled the ROC during a key period of the communist regime. On the one hand, he openly praised the regime and the Soviet Union, and drafted pastoral letters encouraging the priests and the faithful to contribute to the building of the new socialist country and not to oppose the authorities. On the other hand, according to recently opened secret archives, he occasionally acted in ways that could be interpreted as being independent of or even contrary to communist policies. An example is the appointment in positions close to the patriarchal see of former Iron Guard members (Teoctist Arăpașu and Valeriu Anania, among others). Let us highlight some key aspects that could shed light on the motives and actions of Patriarch Justinian during the communist regime, and advance the debate on his resistance or collaboration.

First, Justinian was very close to the leadership of the Communist Party (especially Petru Groza and Gheorghe Gheorghiu-Dej, but not only them), and this friendship and congruence of ideological sympathies meant that, on the one hand, Justinian restricted his actions to appease (and possibly please) the communist authorities and, on the other hand, he possibly had their tacit approval for the way he acted. Many Securitate files make it clear that some Securitate officers perceived Justinian as independently minded and thus opposed to the goals of the party. Remember that these documents reflect the position of the secret agents, not of the high Communist Party officials. In spite of his independence, which was viewed with apprehension and suspicion by the secret political police, nothing happened to Justinian at least during the first ten years of his reign. It was only after he protested the closing of monasteries in 1958 that the Securitate acted against him and placed him under a short-lived form of isolation in a monastery.

Second, the ROC's recruitment of former Iron Guardists paralleled their recruitment in the Communist Party and, as such, was not a gesture of extreme defiance, as Justinian's supporters portray it. Disappointed to discover that the Communist Party numbered only 700 members in August 1944 , communist iron lady Ana Pauker reached out to former legionaries and invited them to join the 
Party "in 'a type of Social Democratic policy' inspired by the French and Italian communist parties' mass recruitment campaigns" (Levy 2001: 74-75). ${ }^{10}$ Pauker needed party members who were compromised or who, given their previous collaboration with the Antonescu regime, could be manipulated and even blackmailed if disobeying the Communist Party. She did so without consulting other party leaders, who later accused her of recruiting new members without verifying their ideological credentials. Many new members were later purged from the party. In 1945, Pauker even extended an olive branch to Iron Guard leader Nicolae Pătrașcu to avoid an armed legionary rebellion against the communists, and released several Iron Guardists from prison (Levy 2001: 75). Both Gheorghiu-Dej and Stalin criticized Pauker's rapprochement with other political formations. As a socialist and fine observer of the communist political landscape, Justinian might have emulated Pauker's policy by reaching out to former Iron Guard priests and monks at a time when he faced their opposition within the Church. A 30 August 1949 Securitate briefing mentioned former legionaries such as Teoctist Arăpașu, Valeriu Anania, Benedict Ghius, Sandu Tudor, and Dumitru Cristescu among those protected and promoted by Justinian. In time, the Securitate's long arm reached out and arrested some of these individuals, especially if the Securitate doubted their support for the new regime. On their release from prison in 1964 or before, these individuals had to sign declarations of allegiance to the regime, many then becoming propaganda tools for the Communist Party. A former political enemy whom Justinian used was Valeriu Anania (who became Metropolitan Bartolomeu of Cluj in 2006-2011). A 30 June 1949 Securitate note reports that, when an acquaintance was surprised to see him holding the high office of a patriarchal inspector, Anania replied: "I did not request this office. Patriarch Justinian himself summoned me up. I told him who I was, that I used to fight at the University of Cluj with other nationalist students against the government, and that the Securitate knew about my past.

\footnotetext{
${ }^{10}$ Manea (2014) also mentions another bizarre episode of fraternization between fascists and communists in Romania against their common enemy at the time, King Carol II: "In 1940 during a pilgrimage at the Rimnicu Sarat prison to celebrate the liberation of their comrades, the legionaries visited the prison of communist women, too. They were interested in meeting and talking to Ana Pauker, whom they called 'The Captain,' a titled their own late leader Corneliu Zelea-Codreanu gave to himself. Immediately after World War II, the famous communist woman in turn called upon the legionaries to join the Communist Party in order to strengthen it and chose as her personal secretary a young, good-looking legionary."
} 
But the Patriarch told me: 'I know it all. That is precisely the sort of man I need. I trust you and want you to be my secretary'."11

Third, Justinian supported the communists due to the mutual advantages the church and the party could provide to one another. It is a well-known fact among Romanians that many of their hierarchs and some priests enjoy material advantages and a lavish lifestyle. Western European church leaders who participated in the canonizations of Romanian saints in Bucharest in 1955 described the riches they encountered among the clergy, compared with the poverty in which ordinary Romanians lived (Leustean 2009: 134-135). Other advantages could be classified as spiritual, although they too had significant material and financial components attached to them: the ROC benefited from the dismantling of the Greek Catholic Church in 1948, when many Greek Catholic properties were transferred to the Orthodox Church, and its bishops, all of whom refused to join the ROC, were placed under arrest in various Orthodox monasteries. The ROC was allowed to canonize a large number of Romanian saints in 1955, a gesture attesting to the close ties it enjoyed with the self-avowed atheistic regime.

Fourth, there is evidence that Justinian, Teoctist, and other Orthodox hierarchs sincerely believed that they were helping their church by collaborating with the communists. Justinian's "useful trade" concept was credited at the time with having rescued Romanian monasticism (at least until 1959), by allowing monks and nuns to earn money by producing exportable goods and thus both avoid the dismantling of their monasteries and live a better life, as one participant in the 1955 canonizations, Bishop James of Malta, reported upon his return from Romania. Other Western participants in those celebrations reported that the slogan "work is prayer" was present throughout the monasteries they visited in and around Bucharest (Leustean 2009: 135-136).

Fifth, some of his close collaborators claimed that Patriarch Justinian was an opponent of the communist regime as early as the 1950s. These claims were believed by some western religious leaders, such as those of the Anglican Church in England, although they were impossible to substantiate from independent

${ }^{11}$ ACNSAS, Collection D, file no. 7755, vol. 3: 182. 
sources. Deacon Vintila, who worked at the patriarchal palace during the 1950s, made such claims in front of John R. Satterthwaite, an envoy to Bucharest of the Archbishop of Canterbury. Satterthwaite reported them as true upon his return to the UK in March 1959. These allegations also hinted to a power struggle between then Metropolitan of Moldova Iustin Moisescu, who was suspected of being a Securitate officer, and Patriarch Justinian, who was presented as a staunch defender of the church who had to face shrewd and immoral rivals (Leustean 2009: 158-159). The communists were using the meetings between Patriarch Justinian and western religious leaders as a golden opportunity to influence western opinion about religious freedom in Romania and the "good" intentions of the communist regime. The regime awarded Patriarch Justinian a medal for faithful performance of his support for the state almost every year.

Sixth, following his 1963 visit to Romania Canon Satterthwaite wrote a report that offered several explanations for Justinian's collaboration with the communists (Leustean 2009: 178-179). According to that report, the Romanian patriarch stated that he was a socialist (not a communist) and that he used his friendship with Gheorghiu-Dej to strengthen the church whenever possible. He encouraged priests to be close to the people in order to avoid a revolt against the communists, and thus a change in the government's attitude toward the church. Leustean hints at other possible reasons for church-state collaboration in communist Romania, including the notion of symphonia and the nationalist version of communism fostered in that country in opposition to the more internationalist version promoted by Moscow.

The duplicitous nature of his actions makes it possible for some to see Justinian as a defender of his church under communism, and for others as a collaborator and supporter of the communist policies against his church. Justinian was a very complex character, a confessed socialist who believed in the ideals of social equality, communitarianism, rural development, and was a close friend of some top communist leaders. He did enjoy, however, a lifestyle and materials advantages far beyond what any proletarian enjoyed under communism, but very similar to the lifestyle of the highest communist elites. That involved a high degree of hypocrisy. He could easily be considered part of 
what the French would derogatorily call the gauche caviar or the English champagne socialists.

\section{Conclusion}

Rereading the history of the ROC during communist times has prompted a lively debate since 1989, with various scholars, journalists, politicians, and church figures taking two main sides, one arguing that the Church mainly collaborated with the communist authorities, the other insisted the Church was a victim of a regime that constantly persecuted it. The figure of Patriarch Justinian Marina has elicited numerous opinions, the more so since the so-called Red Patriarch is considered a towering church figure. Proving that the label of "collaborator" or "opponent" most adequately reflects Justinian's complex activity is beyond the scope of this analysis. Here, we illustrated some of the arguments brought forth in the debate on ROC under communism, and argued that complex cases could be better understood if arguments put forward by both sides of the debate are considered.

\section{Bibliography}

Aioanei, C. and F. Moraru (2001). "Biserica Ortodoxă în lupta cu diavolul roşu," Altarul Banatului 12, 1-3.

Andreescu, G. (2001). "Patriarhul Teoctist: legionar laureat ori comunist promovat?," Observator cultural, (48). Accessed January 29, 2015. http: / / www.observatorcultural.ro/ Patriarhul-Teoctist-legionar-laureatori-comunist-promovat*articleID_3844-articles_details.html

Andrews, C. and V. Mitrokhin. (2001). The Sword and the Shield: The Mitrokhin Archive and the Secret History of the KGB. New York: Basic Books.

Bărbulescu, M., D. Deletant, K. Hitchins, S,. Papacostea, and P. Teodor (2012 [2007]), Istoria României. Bucharest: Corint.

Beeson, T. (1982 [1974]). Discretion and Valour: Religious Conditions in Russia and Eastern Europe. Philadelphia: Collins. 
Caravia, P., V. Constantinescu and F. Stanescu (1999). The Imprisoned Church: Romania, 1944-1989. Bucharest: The National Institute for the Study of Totalitarianism.

Catalan, G. (2003). “Aspecte ale rebeliunii legionare î̀ carterul Antim din Bucurestit," in Despre Holocaust și communism. Iași: Polirom.

Clark, R. (2015). Holy Legionary Youth: Fascist Activism in Interwar Romania. Ithaca, NY: Cornell University Press.

Duca, D. (2007). "Predecesorul lui Teoctist a fost turnător la Secu," Cotidianul, (14 August). Accessed September 5, 2015. http://www.hotnews.ro/stiriarhiva-1041041-predecesorul-lui-teoctist-fost-turnator-secu.htm

Dură, I. (1994). Monahismul Românesc în anii 1948-1989: Mărturii ale românilor si considerații privitoare la acestea. Bucharest: Harisma.

Enache, G. (2005). Ortodoxie și putere politică în România contemporană. Bucharest: Nemira.

—. (2009). "Decretul 410/1959. Un scurt bilanţ la 50 de ani de la adoptare," Ziarul Lumina (28 October). Accessed July 28, 2015. http: / / ziarullumina.ro/ decretul-410-1959-un-scurt-bilan-la-50-de-ani-dela-adoptare-37899.html

Enache, G. and A. Nicolae Petcu (2009). Patriarhul Justinian și Biserica Ortodoxă Română în anii 1948-1964. Galați, Romania: Editura Partener.

Gillet, O. (1997). Religion et nationalisme: l'idéologie de l'Eglise Orthodoxe Roumaine sous le régime communiste. Brussels: Éditions de l'Université de Bruxelles.

Grigore, M. (2015) “The Aiud 'Prison Saints.' History, Memory, and Lived Religion," Eurostudia 10 (1).

Leustean, L. N. (2009). Orthodoxy and the Cold War: Religion and Political Power in Romania, 1947-65. New York: Palgrave Macmillan.

Leustean, L. N. (2014) (ed.). Orthodox Christianity and Nationalism in NineteenthCentury Southeastern Europe. New York: Fordham University Press.

Levy, R. (2001). Ana Pauker: The Rise and Fall of a Jewish Communist. Berkeley, CA: University of California Press.

Manea, N. (2014). “Tovarăşa Ana (I) Paradoxul Pauker: antisemitism şi communism," Observatorul Cultural no. 714 (March). Accessed January 24, 2015. http:// www.observatorcultural.ro/Tovarasa-Ana(I)*articleID_299 24 -articles_details.html 
Păiușan, C. (2005). "Introductory Study," in The Romanian Orthodox Church under the Communist Regime, vol. 1: 1945-1958, in Păiușan and Ciuceanu (2005).

—. (2011). "Relatiile Bisericii Ortodoxe Romane cu Securitatea," Historia.ro (28 June). Accessed August 14, 2015. http://www.historia.ro/exclusiv_web / general/ articol/rela-iile-bisericii-ortodoxe-rom-ne-securitatea

Păiușan, C. and R. Ciuceanu (2005) (eds.). The Romanian Orthodox Church under the Communist Regime, vol. 1: 1945-1958, tr. I. Barbu et al. Bucharest: The National Institute for the Study of Totalitarianism.

Petcu, A. N. (2012). "Preotul Constantin Burducea - când cu steaua, când cu crucea," Ziarul Lumina (12 January). Accessed January 18, 2015. http: / / ziarullumina.ro/ memoria-bisericii / preotul-constantin-burduceacand-cu-steaua-cand-cu-crucea

Sincan, A. (2010). "From Bottom to the Top and Back: On How to Build a Church in Communist Romania," in Christianity and Modernity in Eastern Europe, edited by B. R. Berglund and B. Porter-Szúcs. Budapest: Central European University Press: 208-325

Stan, L. and L. Turcescu (2006). "Politics, National Symbols and the Romanian National Cathedral," Europe-Asia Studies 58 (3): 1119-1139.

- (2007). Religion and Politics in Post-Communist Romania. New York, Oxford University Press.

—. (2010). Religie și politică în România postcomunistă. Updated Romanian translation of Stan and Turcescu (2007). Bucharest: Curtea Veche.

Stănescu, M. (2010-2012). Reeducarea în România comunistă. Bucharest: Polirom.

Turcescu, L. and L. Stan (2010). "The Romanian Orthodox Church and Democratisation: Twenty Years Later," International Journal for the Study of the Christian Church 10, (2-3): 144-159.

Vasile, C. (2005). Biserica Ortodoxă Română în primul deceniu communist. Bucharest: Curtea Veche.

Webster, A. (1995 [1993]). The Price of Prophecy: Orthodox Churches on Peace, Freedom and Security. Washington, DC: Ethics and Public Policy Center. 